Article

\title{
Fermentative Microbes of Khadi, a Traditional Alcoholic Beverage of Botswana
}

\author{
Koketso Motlhanka ${ }^{1, *}$, Kebaneilwe Lebani ${ }^{1}$, Teun Boekhout ${ }^{2,3}$ (D) and Nerve Zhou ${ }^{1}$ \\ 1 Department of Biological Sciences and Biotechnology, Botswana International University of Science \\ and Technology, Private Bag 16, Central District, Palapye 10071, Botswana; lebanik@biust.ac.bw (K.L.); \\ zhoun@biust.ac.bw (N.Z.) \\ 2 Westerdijk Fungal Biodiversity Institute, 3584 CT Utrecht, The Netherlands; t.boekhout@wi.knaw.nl \\ 3 Institute for Biodiversity and Ecosystem Dynamics (IBED), University of Amsterdam, \\ 1098 SM Amsterdam, The Netherlands \\ * Correspondence: koketso.motlhanka@studentmail.biust.ac.bw; Tel.: +267-7632-5058 or +267-7427-6598
}

Received: 18 April 2020; Accepted: 8 May 2020; Published: 11 May 2020

\begin{abstract}
Khadi is a popular traditional alcoholic beverage in rural households in Botswana. The product is produced by fermentation of ripened sun-dried Grewia flava (Malvaceae) fruits supplemented with brown Table Sugar. Despite its popularity, its growing consumer acceptance, its potential nutritional value, and its contribution to the socio-economic lifestyle of Botswana, the production process remains non-standardized. Non-standardized production processes lead to discrepancies in product quality and safety as well as varying shelf life. Identification of unknown fermentative microorganisms of khadi is an important step towards standardization of its brewing process for entrance into commercial markets. The aim of this study was to isolate and identify bacteria and yeasts responsible for fermentation of khadi. Yeasts and bacteria harbored in 18 khadi samples from 18 brewers in central and northern Botswana were investigated using classic culture-dependent techniques and DNA sequencing methods. Additionally, we used the same techniques to investigate the presence of bacteria and yeasts on six batches of ripened-dried G. flava fruits used for production of the sampled brews. Our results revealed that Saccharomyces cerevisiae closely related to a commercial baker's yeast strain sold locally was the most predominant yeast species in khadi suggesting a possible non-spontaneous brewing process. However, we also detected diverse non-Saccharomyces yeasts, which are not available commercially in retail shops in Botswana. This suggests that spontaneous fermentation is partially responsible for fermentation of khadi. This study, presenting the first microbiological characterization of a prominent traditional alcoholic beverage in Botswana, is vital for development of starter cultures for the production of a consistent product towards the commercialization of khadi.
\end{abstract}

Keywords: fermentation; yeast; bacteria; Grewia flava fruits; khadi; traditional alcoholic beverage

\section{Introduction}

The African continent has a variety of traditional alcoholic brews from both cereal- and non-cereal-based substrates [1,2]. Africans of diverse cultures, have used a variety of indigenous substrates that underpin production of novel alcoholic drinks [3]. There is, however, a scarcity of information on the microbial composition of these popular brews in sub-Saharan Africa. In Botswana, a number of traditional alcoholic brews, which include bojwalwa-jwa-setswana, sekhokho, setopoti, bojwalwa-jwa-morula, muchema and khadi dominate household and village markets but they have limited production information or completely lack scientific documentation. 
Khadi is a popular traditional alcoholic beverage well known for its nutritional value and socio-cultural importance by many in Botswana [4]. Khadi is often made from uncontrolled spontaneous fermentation of wild, ripened and sun-dried fruits of Grewia flava (family: Malvaceae) shrubs [5]. Instead of using G. flava fruits, khadi can also be made from other species of Grewia, such as G. occidentalis and G. flavascens known as moretlwa and mokgomphatha in the local Setswana language, as well as from tubers of Kedrostis hirtella (family: Cucurbitaceae, mogakangwaga) and Khadia acutipetala (family: Aizoaceae, khodi) [6]. In some cases, substrates listed above can be mixed to produce khadi with distinct sensory properties. The fruits are soaked in warm water and supplemented with brown Table Sugar. After cooling, previously fermented G. flava fruits are added to the mixture (back-slopping technique) before fermentation commences. The back-slopping process is an inoculum enrichment practice, which involves the use of G. flava fruits collected from the previous batch. These fruits then serve as the source of the active starter cultures, and the procedure is repeated in a limited iterative process. Ethanol content of this alcoholic beverage has been reported to range from $1.7 \%$ to 5.7\% (v/v) [7]. The World Health Organization's global status report on alcohol [8] described khadi as a 'designer alcohol' because the ingredients could be varied to suit consumers' preferences. It is this unique attribute which gives khadi a competitive edge among regional and international alcoholic beverages sold in Botswana.

The major drawbacks of this traditional alcoholic beverage are batch-to-batch differences of product quality, safety and shelf life due to variability in raw materials and non-standardized production methods. The microbiota that drive fermentation also remain unknown. There are no published reports of studies on yeasts and bacteria responsible for khadi fermentation. Conventional and non-conventional yeasts are well known to play an important role in alcoholic fermentations, whereas bacteria are known to be involved in enhancing functional properties of wine through non-alcoholic fermentation [2,9-13]. Isolation and identification of microorganisms responsible for fermentation of khadi is indispensable for the potential development of standardized fermentation processes. This is important for the improvement of fermentation efficiency and production of a quality beverage that can potentially compete in regional and international markets. The aim of this study was to isolate and identify bacteria and yeasts responsible for fermentation of khadi.

\section{Materials and Methods}

\subsection{Sample Collection}

During the survey, $250 \mathrm{~g}$ of ripened sun-dried G. flava fruits and $500 \mathrm{~mL}$ khadi were randomly collected from local khadi brewers. Local fruit harvesters supplied these fruits. Collection of samples was only undertaken in central and northern towns and villages of Botswana (Tonota, Palapye, Serowe, Letlhakane, Mmashoro and Maun) (Figure 1 and Table S1) because khadi brewers in the southern part of Botswana use tubers instead of G. flava fruits for fermentation of khadi. A total of 6 batches of ripened sun-dried G. flava fruits and 18 khadi samples were collected. Fruit samples were collected aseptically using sterile zip-lock bags whereas khadi samples were collected in sterile $500 \mathrm{~mL}$ bottles. Samples were transported to the laboratory at a temperature of $0-4{ }^{\circ} \mathrm{C}$ in a cooler box with frozen ice packs before analyses. All samples were analyzed at most 6 hours after collection. All the khadi samples were purchased from brewers at a stage when they felt that khadi was ready for sale and consumption i.e., after the completion of fermentation.

\subsection{Enumeration of Yeasts and Bacteria}

\subsubsection{Grewia flava Fruits}

A maximum of 5 ripened sun-dried fruits from each of the fruit batches were crushed and re-suspended in $2 \mathrm{~mL}$ PBS (phosphate buffered saline). The mixture was then vortexed for $5 \mathrm{~min}$ and stored on ice. To isolate yeasts, $1 \mathrm{~mL}$ from each sample was pelleted in a micro-centrifuge for $1 \mathrm{~min}$ at $14,000 \times g$. The pellets were then re-suspended in $200 \mu \mathrm{L}$ lysozyme solution $(10 \mathrm{mg} / \mathrm{mL}$ lysozyme; 
$20 \mathrm{mM}$ Tris-HCl; 2mM EDTA; 1\% Triton X-100 (pH 8)) and maintained at room temperature for $30 \mathrm{~min}$ to lyse the bacteria [14]. $100 \mu \mathrm{L}$ of 10 -fold serially diluted samples (in $1 \times \mathrm{PBS}$ ) was spread plated on yeast peptone dextrose (YPD) agar ( $2 \%$ glucose; $1 \%$ yeast extract; $2 \%$ peptone; and $1.5 \%$ agar, at a $\mathrm{pH}$ of 6.2) supplemented with a cocktail of antibiotics $(100 \mu \mathrm{g} / \mathrm{mL}$ streptomycin, $100 \mu \mathrm{g} / \mathrm{mL}$ penicillin; and $100 \mu \mathrm{g} / \mathrm{mL}$ ampicillin) for selective growth of yeasts before enumeration. The plates were incubated at $30{ }^{\circ} \mathrm{C}$ for 48 to $72 \mathrm{hrs}$. After incubation, colony-forming units (CFU) were counted and expressed as $\log$ colony-forming units per milliliter $\left(\log _{10} \mathrm{CFU} / \mathrm{mL}\right)$. For further studies, representatives of morphologically distinct colonies were picked, observed under a microscope (DE/Axioplan 2; Carl Zeiss, Oberkochen, Germany), sub-cultured twice on YPD plates and then cryopreserved at $-80^{\circ} \mathrm{C}$ in $25 \%$ glycerol. To isolate bacteria, the samples were serially diluted and spread on Luria broth (LB) agar $(1 \% \mathrm{NaCl} ; 1 \%$ peptone; $0.5 \%$ yeast extract; and $1.5 \%$ agar at a $\mathrm{pH}$ of 7.4$)$ supplemented with $10 \mu \mathrm{g} / \mathrm{mL}$ of cycloheximide to select against yeasts. After incubation at $37^{\circ} \mathrm{C}$ for 24 to $72 \mathrm{hrs}$, a minimum of 5 representatives of different bacteria and yeast colonies were purified and stored as mentioned above. The experiments were performed in triplicate.
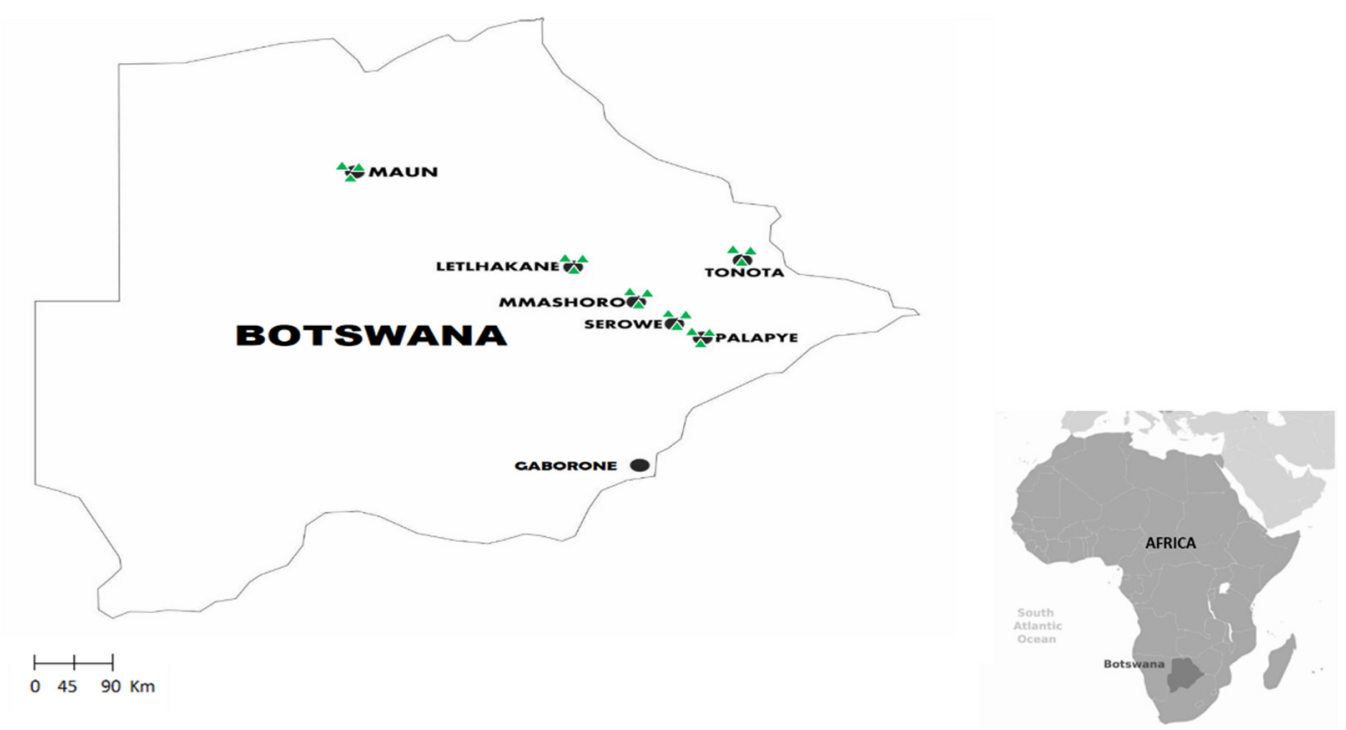

Figure 1. Map of sampling areas across Botswana. The map shows the locations in the central and northern parts of Botswana (black dots) from which ripened sun-dried G. flava fruits and khadi were collected. The green triangles show the number of replicates per location.

\subsubsection{Khadi}

Aliquots from all khadi samples were 10-fold serially diluted in PBS and kept on ice. $100 \mu \mathrm{L}$ of the aliquots $\left(10^{0}\right.$ to $\left.10^{-6}\right)$ were plated on either antibiotic supplemented YPD or antifungal supplemented LB agar media to enumerate yeasts or bacteria, respectively, as described in the section above (2.2.1). De Man, Rogosa and Sharpe agar (MRS agar) plates (CONDA Laboratory, Spain) supplemented with $10 \mu \mathrm{g} / \mathrm{mL}$ of cycloheximide were used to determine and enumerate lactic acid bacteria (LAB). Plates were incubated at $37^{\circ} \mathrm{C}$ under partial anaerobic conditions $\left(10 \%\right.$ of $\left.\mathrm{CO}_{2}\right)$ for $72 \mathrm{hrs}$. Colonies were counted and expressed as $\log$ colony-forming units per milliliter $\left(\log _{10} \mathrm{CFU} / \mathrm{mL}\right)$. The experiments were performed in triplicate.

\subsection{Identification of Yeast and Bacteria Using Polymerase Chain Reaction (PCR)}

\subsubsection{Yeasts}

A single colony from each of the yeast isolates with distinct morphological features was picked and purified by re-streaking on YPD agar plates. These colonies were then re-suspended in $50 \mu \mathrm{L}$ of 
sterile deionized water. The suspension was then boiled at $98{ }^{\circ} \mathrm{C}$ for $15 \mathrm{~min}$ and then centrifuged for $1 \mathrm{~min}$ at $16,000 \times g$ using a micro-centrifuge. Two $\mu \mathrm{L}$ of the supernatant was then used as a template for polymerase chain reaction (PCR) amplification of a $560 \mathrm{bp}$ DNA fragment of the D1/D2 region of the $26 \mathrm{~S}$ rDNA using universal PCR primers, NL1 (5'-GCATATCAATAAGCGGAGGAAAAG-3') and NL4 (5'-GGTCCGTGTTTCAAGACGG-3') as reported elsewhere $[15,16]$. PCR amplification was performed using ProFlex PCR Systems (Applied Biosystems, USA) in a $20 \mu \mathrm{L}$ reaction volume containing $2.5 \mu \mathrm{L} 10 \times$ PCR buffer, $2.0 \mu \mathrm{M}$ of each primer, $0.2 \mathrm{mM}$ dNTPs, and $1.25 \mathrm{U}$ Taq DNA polymerase (Takara Bio Inc., Japan) using the following cycling conditions: initial denaturation at $98^{\circ} \mathrm{C}$ for $3 \mathrm{~min}$; 38 cycles of denaturation $\left(98^{\circ} \mathrm{C}\right.$ for $\left.15 \mathrm{~s}\right)$, annealing $\left(54^{\circ} \mathrm{C}\right.$ for $1 \mathrm{~min}$ ), and extension $\left(72{ }^{\circ} \mathrm{C}\right.$ for $1 \mathrm{~min}$ ), a final extension step at $72{ }^{\circ} \mathrm{C}$ for $7 \mathrm{~min}$ and held at $4{ }^{\circ} \mathrm{C}$ until required. Negative controls in which the template DNA in the PCR mixture was replaced with sterile distilled water were also included. All amplicons were purified using a QIAquick PCR product purification kit (Qiagen, GmBH, Germany) according to manufacturer's instructions. The amplicons were sequenced by Inqaba Biotech (Pretoria, South Africa). SnapGene®Viewer software ver. 4.2.11 (GSL Biotech) sequence editing tool was used to generate contiguous sequences (http://www.snapgene.com). Species identification was done by using nucleotide Basic Local Alignment Search Tool (BLASTn) (https://blast. ncbi.nlm.nih.gov/Blast.cgi?PROGRAM=blastn\&PAGE_TYPE=BlastSearch\&LINK_LOC=blasthome) as well as using pairwise identification tool available on the Westerdijk Fungal Biodiversity Institute strain database, (http://www.westerdijkinstitute.nl/). A commercial baker's yeast (S. cerevisiae) obtained from a local supermarket was used as the control in this study (Anchor Yeast, South Africa). It should be noted that there are no retail outlets in Botswana that sell commercial brewer's yeast that could have been used as another control for this aspect of the study.

\subsubsection{Bacteria}

Genomic DNA was extracted using the GenElute ${ }^{\text {TM }}$ Bacterial Genomic DNA Kit (Sigma-Aldrich, USA) according to manufacturer's instructions. The extracted genomic DNA was used for PCR amplification as in Section 2.3.1, except that $16 \mathrm{~S}$ rDNA was amplified using a different pair of universal primers, pAF (5'-AGAGTTTGATCCTGGCTCAG-3') and pER (5'-CCGTCAATTCCTTTGAGTTT-3') [17] and the following cycling conditions; initial denaturation at $98^{\circ} \mathrm{C}$ for $30 \mathrm{~s}, 35$ cycles of denaturation $\left(98^{\circ} \mathrm{C}\right.$ for $\left.30 \mathrm{~s}\right)$, annealing $\left(47^{\circ} \mathrm{C}\right.$ for $\left.30 \mathrm{~s}\right)$, and extension $\left(72{ }^{\circ} \mathrm{C}\right.$ for $\left.30 \mathrm{~s}\right)$, a final extension step at $72{ }^{\circ} \mathrm{C}$ for $7 \mathrm{~min}$ and held at $4{ }^{\circ} \mathrm{C} \infty$. Negative controls were as above. PCR product purification, sequencing and identification of bacteria were done as in Section 2.3.1.

\subsubsection{Phylogenetic Analyses}

To determine the relationship of the microbial isolates from the G. flava fruits and khadi samples, we used MEGA 7.0.26 software [18]. The sequences were aligned using MUSCLE within the MEGA software and then the aligned sequences were used to calculate the best maximum likelihood model (Jukes-Cantor, Kimura 2-parameter, Tamura 3-parameter, Hasegawa-Kishino-Yano, Tamura-Nei and General time reversible models) to be used to construct the phylogenetic tree [19].

\subsubsection{In Silico PCR-Restriction Fragment Length Polymorphism (RFLP) to Profile Yeasts Driving Khadi Fermentation}

We sought to investigate whether the khadi brewers used a strain of a commercial yeast species as starter cultures or whether they depend on naturally occurring yeasts. To do so, we performed an in silico PCR-RFLP (restriction fragment length polymorphism) test using the D1/D2 domain of the 26S rDNA amplicons with a SnapGene®Viewer software ver.4.2.11 (GSL Biotech) (http://www.snapgene.com). The inbuilt gel electrophoresis simulation option with a set parameter of $4 \%$ agarose gel option was chosen for visualization after an in-silico digestion with the following restriction enzymes; GluI, HaeIII, HinfI and RsaI. pUC19 - Sau3AI digest was selected as a molecular weight ladder to compare the sizes of the restricted fragments. 
The D1/D2 domain of the 26S rDNA sequences of the commercial yeast species, namely ale yeast (Saccharomyces cerevisiae, SafAle T58, Fermentis, France), lager yeast (Saccharomyces pastorianus, Lallemand Brewing, Austria) and wine yeast (Saccharomyces cerevisiae, Lalvin EC-1118 and RC-212) were downloaded from NCBI (https://www.ncbi.nlm.nih.gov/). These were ran in parallel with commercial baker's yeast (Saccharomyces cerevisiae, Anchor Yeast, South Africa). Restriction fragment patterns of non-Saccharomyces yeasts found in khadi from across Botswana were also investigated using in silico RFLP as detailed above.

\subsection{Ethanol Assays}

Khadi samples were centrifuged and the resultant cell-free supernatant was used to determine the ethanol content. An enzymatic ethanol assay kit (K-ETOH 08-18, Megazyme, Ireland) was used according to the manufacturer's instructions. The samples were analyzed in triplicate.

\subsection{Statistical Analyses}

One-way analysis of variance (ANOVA) was used to compare differences among the colony forming units of khadi samples (Microsoft Office 2019, USA).

\section{Results and Discussion}

\subsection{Abundance of Yeasts and Bacteria from Grewia Flava Fruits and Khadi}

\subsubsection{Grewia flava Fruits}

Grewia flava fruits play an important role in khadi fermentation in northern Botswana as the source of the fermenTable Sugars in addition to supplemented table brown sugar. These fruits could also be the source of fermenting microorganisms during spontaneous fermentation. For this reason, we enumerated the yeasts and bacteria found on ripened and sun-dried G. flava fruits used to produce khadi. We noted that in each area there was a single supplier of locally collected batches of G. flava fruits and hence only one batch of fruits per town or village was used for investigation. There were lower numbers of yeasts as compared to bacteria. On average, $1.0 \times 10^{3} \log _{10} \mathrm{CFU} / \mathrm{mL}$ of yeasts were observed as compared to $3.5 \times 10^{3} \log _{10} \mathrm{CFU} / \mathrm{mL}$ colonies of bacteria (Table 1 ). The colonization of fruits by bacteria and yeasts is well described [20] but the low number of both bacterial and yeast colonies observed could be attributed to the storage and processing of the fruits. The drying and storage of the fruits before fermentation could have created a selective environment for proliferation of relative few yeasts and bacteria with specific attributes that allow them to survive in a new environment [21].

Table 1. Abundance of yeasts and bacteria isolated from the ripened sun-dried G. flava fruits samples expressed in $\log { }_{10} \mathrm{CFU} / \mathrm{mL}$ (colony forming units per millimeter).

\begin{tabular}{ccc}
\hline \multirow{2}{*}{ Sample } & \multicolumn{2}{c}{$\log _{\mathbf{1 0}} \mathbf{C F U} / \mathbf{m L}$} \\
\cline { 2 - 3 } & Yeasts & Bacteria \\
\hline Letlhakane & 3.0 & 3.6 \\
Maun & 3.0 & 3.5 \\
Mmashoro & 0 & 3.6 \\
Palapye & 3.3 & 3.3 \\
Serowe & 3.0 & 3.6 \\
Tonota & 3.0 & 3.6 \\
Average & 2.6 & 3.5 \\
\hline
\end{tabular}

\subsubsection{Khadi}

After the enumeration of yeasts and bacteria on dried fruits, we sought to perform the same enumeration in the final fermentation product, khadi. Interestingly, even though bacteria were found 
on dried fruits, none were found in all khadi samples investigated. Although the role of bacteria during the progression of fermentation in other alcoholic beverages has been described [22,23], their role during the progression of khadi fermentation was not investigated in this study. Since the ripened sun-dried fruits were sampled before fermentation and the final product after fermentation, the absence of bacteria at the end of fermentation could be the due to their role in the early stages of fermentation, their inhibition by the accumulation of ethanol, as well as out-competition by yeasts. The total number of yeasts on the khadi samples ranged from $5.1 \pm 0.09 \log _{10}$ CFU/mL (Mmashoro) to $6.4 \pm 0.22 \log _{10}$ $\mathrm{CFU} / \mathrm{mL}$ (Palapye) (Figure 2). On average, $5.6 \pm 0.57 \log _{10} \mathrm{CFU} / \mathrm{mL}$ of yeasts were recorded. The yeast CFU recorded from the ripened and dried G. flava fruits were lower as compared to those recorded from the khadi samples. There was no statistically significant difference in concentrations of yeasts at the end of fermentation among the 18 khadi samples (one-way ANOVA; $\mathrm{p}<0.05$ ).

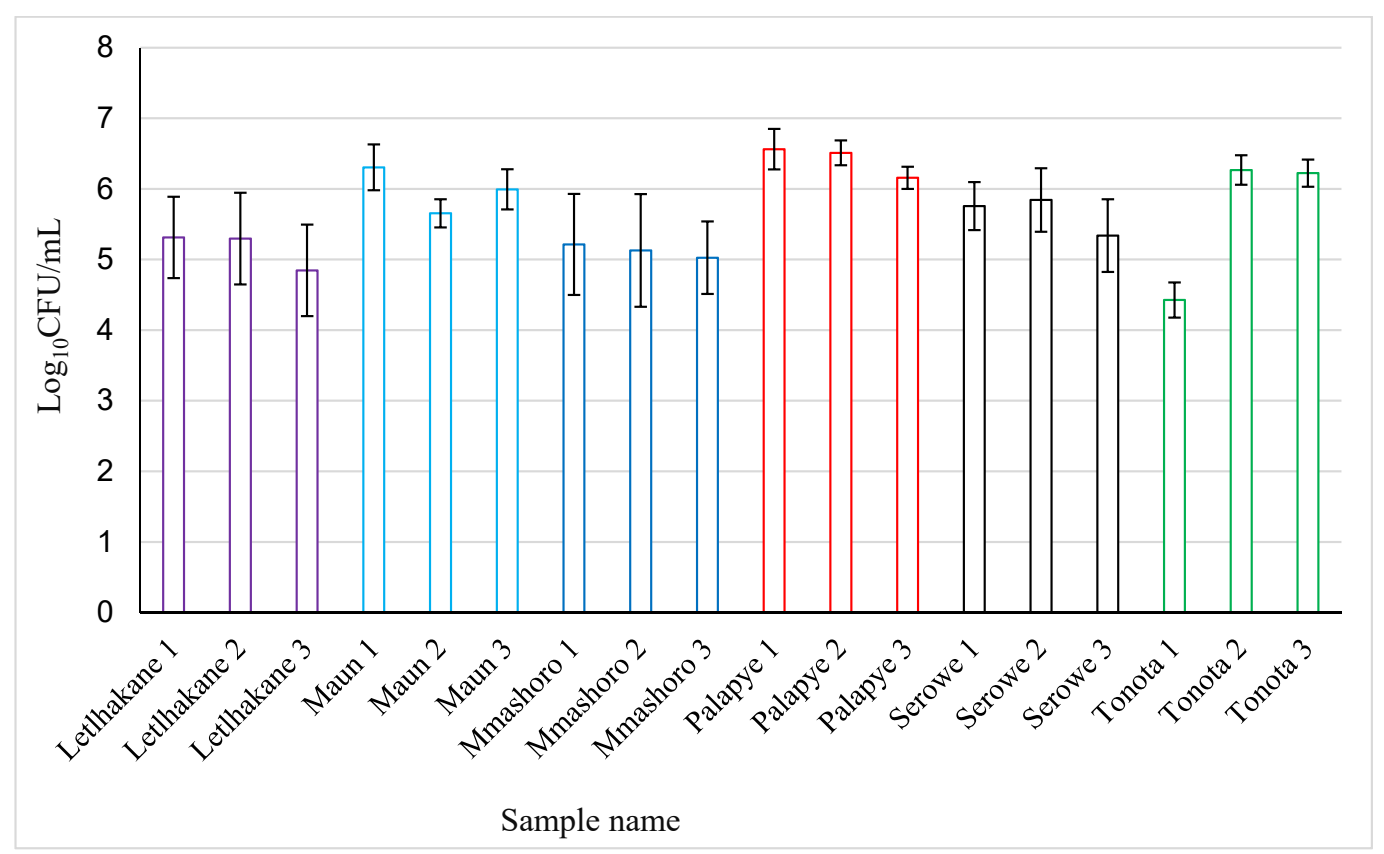

Figure 2. Variability of amounts of yeast $\left(\log _{10} \mathrm{CFU} / \mathrm{mL}\right)$ isolated from khadi samples from different parts of the central and northern Botswana. Six samples were collected in triplicate and analyzed individually. Color code: purple = Letlhakane, sky blue = Maun, navy blue = Mmashoro, red = Palapye, Black $=$ Serowe and green $=$ Tonota .

\subsection{Diversity of Microbial Isolates from Grewia Flava Fruits}

\subsubsection{Yeasts}

The diversity of resident communities of yeasts on the dried fruits have the potential to shape the fermentation and the outcome of the alcoholic beverage. We therefore sought to examine the diversity of yeasts on dried G. flava fruit surfaces by sequencing the D1/D2 domains of the 26S rDNA. Six species of yeast-like fungi and yeasts dominated the fruit samples, namely Aureobasidium leucospermi, Aureobasidium melanogenum, Naganishia diffluens, Aureobasidium spp., Aureobasidium pullulans and Saccharomyces cerevisiae (Table 2). All of the above species except $S$. cerevisiae have been previously reported to tolerate arid environments [24] typical of the Botswanan climate. The identification of these fruit resident yeasts posed a question of whether they could be responsible for fermentation of khadi. Interestingly, Aureobasidium spp. have been reported to be among the main non-conventional yeasts known to be involved in spontaneous alcoholic fermentations of wine, beer, tequila, mezcal and cachaça $[25,26]$. Although basidiomycetous yeasts have been isolated from fruits and fermented products [2,27], their role in khadi fermentation remains unknown. S. cerevisiae, a well-known fermenting 
yeast inhabiting sugar rich environment such as wild fruits, was only isolated from Letlhakane samples. Its rarity and presence in low frequencies on fruits before fermentation commences is not surprising [28-32]. The species eventually dominates fermentation after engineering the ecosystem through its robust make-accumulate-consume fermentative lifestyle irrespective of the presence of oxygen [30-33].

Table 2. Identity of yeasts isolated from ripened and dried G. flava fruits.

\begin{tabular}{ccccc}
\hline Species Name & Isolate Number & $\begin{array}{c}\text { Collection } \\
\text { Number }\end{array}$ & $\begin{array}{c}\text { Accession } \\
\text { Number }\end{array}$ & Identity (\%) \\
\hline Aureobasidium leucospermi & D2 & Palapye & KX893326.1 & 99 \\
Aureobasidium melanogenum & D3 & Serowe & MF370933.1 & 99 \\
Aureobasidium pullulans & D6 & Tonota & MF979210.1 & 99 \\
Aureobasidium spp. & D5 & Maun & KT361586.1 & 99 \\
Naganishia diffluens & D4 & Palapye & KU316762.1 & 99 \\
Saccharomyces cerevisiae & D7 & Letlhakane & HQ108377.1 & 99 \\
\hline
\end{tabular}

\subsubsection{Bacteria}

Bacteria are known to play a role in enhancing the functional properties of alcoholic beverages such as wine, through non-alcoholic fermentation, producing products such as organic acids which impart complex flavor profiles [22,23]. Bacteria are sympatric to yeasts on sugar rich environments such as fruits $[26,34]$. We sought to investigate the diversity of bacteria on G. flava fruits as they likely contribute to shape the quality of the end product, khadi. A total of 21 phylogenetically diverse bacterial isolates (Table 3) were recorded. Bacillus species surprisingly dominated the isolates accounting for $76.2 \%$ of the identified isolates (16 out of 21). The dominance of Bacillus species could be due to the isolation media we used in this study, method of handling and storage of fruits, which probably favored their proliferation or their natural abundance on G. flava fruits. It should be noted that ripened G. flava fruits are sun dried and packaged in repurposed bags before being sold to local brewers. This suggests that the processing of ripened sun-dried fruits probably selects for ultraviolet (UV)-resistant spores of Bacillus species [35] which then dominate the dried fruits isolates. Acinetobacter lwoffii, Desemzia incerta, Exiguobacterium indicum and Staphylococcus saprophyticus were the only non-Bacillus bacteria isolated from ripened and dried fruits. A. lwoffii is associated with skin microbiota probably introduced during the processing of fruits [36,37]. Staphylococcus saprophyticus has been reported to inhabit a fruit niche [26,38], hence could be associated with G. flava fruits in this study. We did not detect any lactic acid bacteria (LAB) from the fruits.

Table 3. Identity of bacteria isolated from Grewia flava fruits based on D1/D2 region of the 16S rDNA.

\begin{tabular}{|c|c|c|c|c|}
\hline Species Name & Isolate Number & $\begin{array}{c}\text { Collection } \\
\text { Number }\end{array}$ & $\begin{array}{c}\text { Accession } \\
\text { Number }\end{array}$ & Identity (\%) \\
\hline Acinetobacter lwoffii & MMB4 & Mmashoro & KF818633.1 & 99 \\
\hline Acinetobacter lwoffii & SB2 & Serowe & KF818633.1 & 99 \\
\hline Bacillus cereus & TB3 & Tonota & AB523744.1 & 99 \\
\hline Bacillus cereus & LB4 & Letlhakane & MG021182.1 & 99 \\
\hline Bacillus methylotrophicus & SB1 & Serowe & KM659219.1 & 99 \\
\hline Bacillus amyloliquefaciens subsp. plantarum & MMB2 & Mmashoro & JN661699.1 & 99 \\
\hline Bacillus spp. & MAB3 & Maun & KF646681.1 & 99 \\
\hline Bacillus spp. & TB4 & Tonota & KT443870.1 & 99 \\
\hline Bacillus thuringiensis & SB3 & Serowe & KY910253.1 & 99 \\
\hline Bacillus thuringiensis & LB3 & Letlhakane & KY495218.1 & 99 \\
\hline Bacillus velezensis & MMB1 & Mmashoro & MH000677.1 & 99 \\
\hline Desemzia incerta & TB2 & Tonota & KF712891.1 & 99 \\
\hline Exiguobacterium indicum & MAB1 & Maun & MH819520.1 & 93 \\
\hline Staphylococcus saprophyticus & MAB2 & Maun & СР022093.2 & 99 \\
\hline
\end{tabular}




\subsection{Diversity of Yeasts from the Fermented Brew, Khadi}

Mainly Saccharomycotina and a few Basidomycota yeasts were isolated from all the brews. This observation was not surprising, as Saccharomycotina yeasts are known to engineer the environment that favors their proliferation through fermentation [30]. Alcoholic fermentation is a niche reconstruction lifestyle of Crabtree positive yeasts which creates heat, $\mathrm{CO}_{2}$ and ethanol to inhibit the growth of competitors $[30,33,39]$. The limited diversity of yeasts on the dried fruits in comparison to the wide diversity of bacteria prompted further investigation to establish which microorganisms could be responsible for the fermentation of khadi. A total of 74 yeast isolates with a wide phylogenetic diversity were recorded from different khadi samples (Table 4, Figure 3). The isolates belonged to 13 yeast species (Table 5). Interestingly, most of those yeasts were not isolated from the ripened sun-dried fruits. There are two possibilities to explain this, one is that there was a source of yeasts other than those from the wild fruits, and the other is that those yeasts were rare on the fruit surfaces. S. cerevisiae dominated the isolates (51.4\%) followed by Candida ethanolica (12.2\%) and Saccharomycodes ludwigii $(10.8 \%)$ (Tables 4 and 5). The dominance of $S$. cerevisiae at the end of the alcoholic fermentation, despite the dominance of non-conventional yeasts and bacteria, during the early stages of fermentation is well documented $[25,30,32]$. These results suggest that khadi is a product of mixed-culture fermentation with phylogenetically diverse yeasts dominated by $S$. cerevisiae (Table 4).

Mixed-culture fermentations made up of conventional and non-conventional yeasts leads to distinctive aromatic profiles of alcoholic beverages [40-44]. The production of aroma compounds in alcoholic beverages also requires non-conventional yeasts. For example, Lachancea spp. are well-known producers of fruity esters, which impart a characteristic fruity flavor to alcoholic brews [45-47]. Fermentative species of the genus Candida, such as C. ethanolica and C. sake, also known to generate unique flavors of a brew, were isolated [48] in brews from Letlhakane, Tonota and Maun. However, the isolation of spoilage yeasts, such as Brettanomyces spp. and Zygosaccharomyces spp. [49-51], in samples from Serowe and Tonota, respectively, could negatively impact on the quality of a spontaneously fermented brew. Brettanomyces bruxellensis has been isolated from beverages such as wines which characteristically develop unpleasant and distinctive aromas due to the production of volatile phenolic compounds and diacetyl. These "Brett taints" are normally associated with the smell of barnyards, burnt plastic, wet animals and horse sweat [50,52-54], but on a positive note, Brettanomyces spp. can also be used in the production of Lambic beers [55]. Brettanomyces spp. have been reported to produce high amounts of ethyl esters which contribute to the overall fruity or floral character of the beverage [56]. Zygosaccharomyces bailii is a wine spoilage yeast associated with grapes whose spoilage is characterized by generation of taints, odors, off-flavors, development of hazes, and excessive gas production [26,49]. Research also shows that Z. bailii can improve the flavor complexity of alcoholic beverages either used individually or as a mixed culture with $S$. cerevisiae producing flavor compounds such as alcohols, acids, esters, ketones and aldehydes [57]. A concern for spontaneously fermented brews is the presence of clinically relevant species. Pichia kudriavzevii (also known as Candida krusei [58]) was the only potentially opportunistic pathogen [58] that was isolated and it was found in a Letlhakane sample. However, P. kudriavzevii also has good fermentation characteristics and it has been previously isolated from taruba, grapes and masau fruits [1,32,59]. 
Table 4. Identity of yeast isolates from the khadi samples based on D1/D2 domains of 26S rDNA.

\begin{tabular}{|c|c|c|c|c|}
\hline Species Name & Isolate Number & $\begin{array}{c}\text { Collection } \\
\text { Number }\end{array}$ & $\begin{array}{c}\text { Accession } \\
\text { Number }\end{array}$ & Identity (\%) \\
\hline \multicolumn{5}{|c|}{ Saccharomyces yeasts } \\
\hline Saccharomyces cerevisiae & $\mathrm{Z2}$ & Letlhakane 1 & KX428522.1 & 99 \\
\hline Saccharomyces cerevisiae & L3 & Letlhakane 1 & MG773372.1 & 99 \\
\hline Saccharomyces cerevisiae (2) & L6 and L10 & Letlhakane 2 & MG017580.1 & 99 \\
\hline Saccharomyces cerevisiae & L7 & Letlhakane 2 & LC336457.1 & 99 \\
\hline Saccharomyces cerevisiae & L8 & Letlhakane 3 & MF979228.1 & 99 \\
\hline Saccharomyces cerevisiae & L11 & Letlhakane 3 & HM191639.1 & 99 \\
\hline Saccharomyces cerevisiae & LMA1 & Letlhakane 2 & MF979228.1 & 99 \\
\hline Saccharomyces cerevisiae & LMA3 & Letlhakane 2 & KY109286.1 & 99 \\
\hline Saccharomyces cerevisiae & LMA4 & Letlhakane 1 & СР022977.1 & 99 \\
\hline Saccharomyces cerevisiae & LMA5 & Letlhakane 2 & KM234472.1 & 99 \\
\hline Saccharomyces cerevisiae & LMB1 & Letlhakane 2 & KX119942.1 & 99 \\
\hline Saccharomyces cerevisiae & MA1 & Maun 1 & KX428522.1 & 99 \\
\hline Saccharomyces cerevisiae & MA6 & Maun 2 & HM107789.1 & 99 \\
\hline Saccharomyces cerevisiae & AC1MIII & Mmashoro 3 & MG641152.1 & 99 \\
\hline Saccharomyces cerevisiae (2) & $\begin{array}{l}\text { AC2MIII and } \\
\text { BC1MII }\end{array}$ & Mmashoro 3 and 2 & HM101473.1 & 99 \\
\hline Saccharomyces cerevisiae & AC3MIII & Mmashoro 3 & MF406146.1 & 99 \\
\hline Saccharomyces cerevisiae & AC5MIII & Mmashoro 3 & JN225410.1 & 99 \\
\hline Saccharomyces cerevisiae & BC4MII & Mmashoro 2 & JX141335.1 & 99 \\
\hline Saccharomyces cerevisiae & MIAC1 & Mmashoro 1 & KM103041.1 & 99 \\
\hline Saccharomyces cerevisiae & MIAC3 & Mmashoro 1 & MF406146.1 & 99 \\
\hline Saccharomyces cerevisiae & MIAC2 & Mmashoro 1 & KM103042.1 & 99 \\
\hline Saccharomyces cerevisiae & MIAC5 & Mmashoro 1 & MK027354.1 & 99 \\
\hline Saccharomyces cerevisiae & P10 & Palapye 1 & KY109242.1 & 99 \\
\hline Saccharomyces cerevisiae & P11 & Palapye 1 & HQ443692.1 & 99 \\
\hline Saccharomyces cerevisiae & P13 & Palapye 3 & HM101472.1 & 99 \\
\hline Saccharomyces cerevisiae (2) & P14 and P16 & Palapye 2 & KX098507.1 & 99 \\
\hline Saccharomyces cerevisiae & P17 & Palapye 3 & GU080046.1 & 99 \\
\hline Saccharomyces cerevisiae (2) & S2 and S7 & Serowe 1 & GU080049.1 & 99 \\
\hline Saccharomyces cerevisiae & S6 & Serowe 2 & GU080046.1 & 99 \\
\hline Saccharomyces cerevisiae & $\mathrm{T} 5$ & Tonota 1 & MF406147.1 & 99 \\
\hline Saccharomyces cerevisiae & T6 & Tonota 1 & HM101472.1 & 99 \\
\hline Saccharomyces cerevisiae & $\mathrm{T} 8$ & Tonota 1 & JX141335.1 & 99 \\
\hline Saccharomyces cerevisiae & T9 & Tonota 2 & MK027354.1 & 99 \\
\hline Saccharomyces cerevisiae & $\mathrm{T} 11$ & Tonota 2 & MF498873.1 & 99 \\
\hline $\begin{array}{c}\text { Saccharomyces cf. } \\
\text { cerevisiae/paradoxus (2) }\end{array}$ & $\begin{array}{l}\text { AC4MIII and } \\
\text { MIAC4 }\end{array}$ & Mmashoro 1 and 3 & KY109333.1 & 99 \\
\hline \multicolumn{5}{|c|}{ Non-Saccharomyces yeasts } \\
\hline Brettanomyces bruxellensis & S5 & Serowe 2 & KY107600.1 & 99 \\
\hline Candida ethanolica & LMB2 & Letlhakane 3 & KY283163.1 & 99 \\
\hline Candida ethanolica (2) & LMB4 and LMC1 & Letlhakane 1 & FM180545.1 & 99 \\
\hline Candida ethanolica & LMC4 & Letlhakane 1 & JX880409.1 & 99 \\
\hline Candida ethanolica (5) & $\begin{array}{c}\text { T10, T14 T15, T17, } \\
\text { T18 }\end{array}$ & Tonota 2 and 3 & JX880409.1 & 99 \\
\hline Candida sake (2) & MA2 and MA3 & Maun 1 & JX880410.1 & 99 \\
\hline $\begin{array}{l}\text { Curvibasidium } \\
\text { pallidicorallinum }\end{array}$ & MA7 & Maun 3 & JX188149.1 & 99 \\
\hline Pichia kudriavzevii & L13 & Letlhakane 3 & AY529504.1 & 99 \\
\hline Pichia kudriavzevii & S8 & Serowe 3 & AY529504.1 & 91 \\
\hline Lachancea fermentati & MA4 & Maun 2 & KY108224.1 & 99 \\
\hline Lachancea fermentati & MA8 & Maun 3 & KM234440.1 & 99 \\
\hline Lachancea fermentati & $\mathrm{P} 18$ & Palapye 3 & KM234440.1 & 99 \\
\hline Pichia kudriavzevii & L1 & Letlhakane 1 & KM234442.1 & 99 \\
\hline Pichia kudriavzevii (2) & L2 and L4 & Letlhakane 2 & KF214396.1 & 99 \\
\hline Pichia manshurica & P15 & Palapye 2 & MK034750.1 & 99 \\
\hline Rhodotorula nothofagi & Z1 & Letlhakane 1 & KJ794722.1 & 99 \\
\hline Saccharomycodes ludwigii (2) & L9 and L12 & Letlhakane 3 & FM180540.1 & 99 \\
\hline Saccharomycodes ludwigii (2) & $\mathrm{S} 1$ and S4 & Serowe 1 & FM180540.1 & 99 \\
\hline Saccharomycodes ludwigii (4) & $\mathrm{T} 7, \mathrm{~T} 13, \mathrm{~T} 12, \mathrm{~T} 16$ & Tonota 1 and 2 & FM180540.1 & 99 \\
\hline Schizosaccharomyces pombe & P8 & Palapye 2 & KY296084.1 & 99 \\
\hline Zygosaccharomyces bailii & $\mathrm{T} 1$ & Tonota 1 & GU080052.1 & 99 \\
\hline Zygosaccharomyces bailii & $\mathrm{T} 4$ & Tonota 1 & KY296086.1 & 99 \\
\hline
\end{tabular}

Note: The number in the brackets shows isolates with the name and same accession number. 


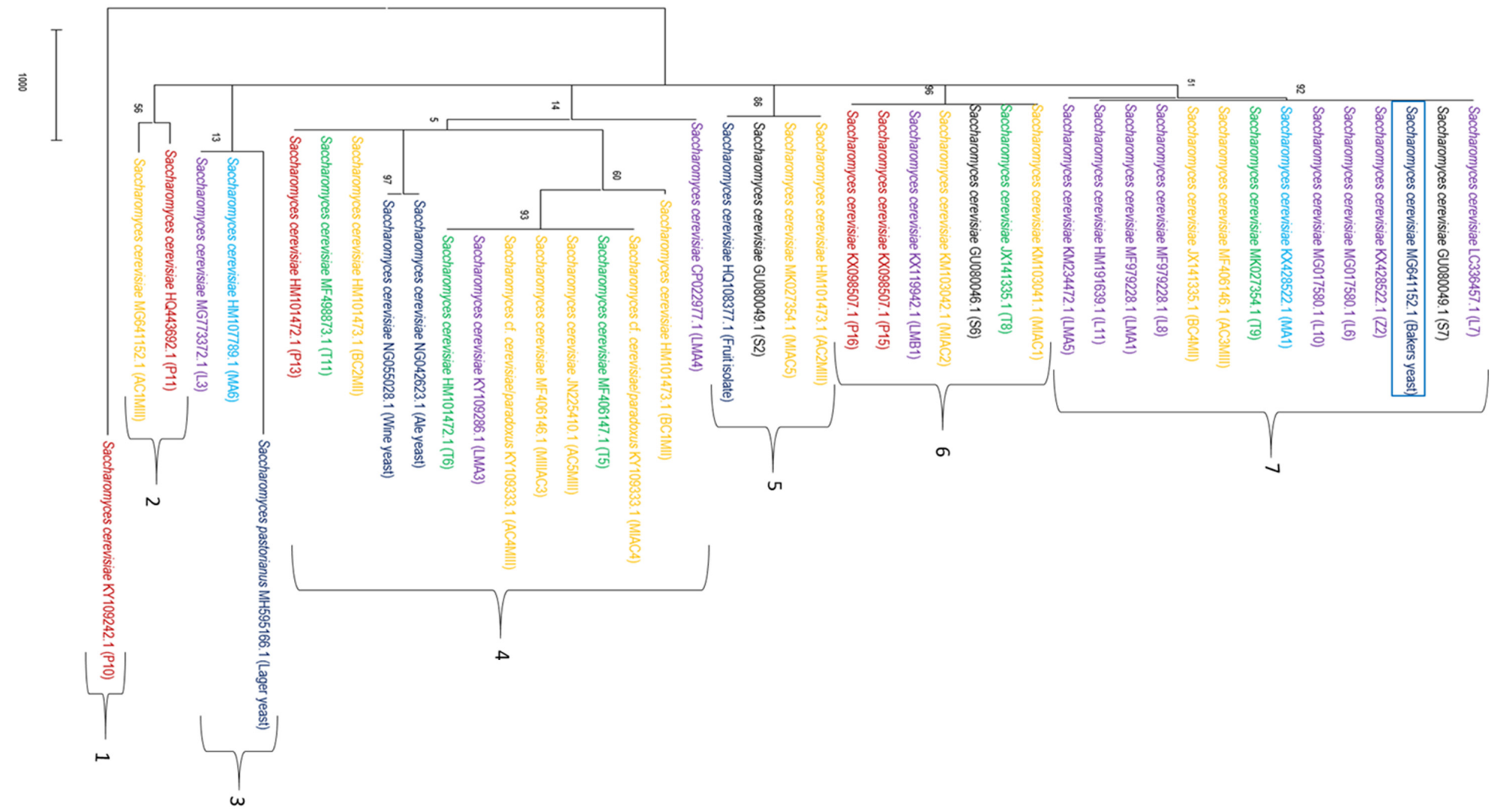

Figure 3. Maximum likelihood analysis of the D1/D2 domains of 26S rDNA of Saccharomyces yeasts isolated from khadi samples. The evolutionary relationship between isolates was inferred using the maximum likelihood method based on the Hasegawa-Kishino-Yano model [19]. Evolutionary analyses were conducted in MEGA7 [18]. Color code: purple $=$ Letlhakane, sky blue $=$ Maun, yellow $=$ Mmashoro, red $=$ Palapye, Black $=$ Serowe, green $=$ Tonota and navy blue $=$ Controls . 
Table 5. Diversity of yeasts from the khadi samples.

\begin{tabular}{|c|c|c|c|c|c|c|c|c|}
\hline Species & $\begin{array}{c}\text { Number of } \\
\text { Isolates Sequenced }\end{array}$ & $\%$ & Letlhakane & Maun & Mmashoro & Palapye & Serowe & Tonota \\
\hline Saccharomyces cerevisiae & 38 & 51.4 & 12 & 2 & 10 & 6 & 3 & 5 \\
\hline Candida ethanolica & 9 & 12.2 & 4 & & & & & 5 \\
\hline Saccharomycodes ludwigii & 8 & 10.8 & 2 & & & & 2 & 4 \\
\hline Zygosaccharomyces bailii & 2 & 2.7 & & & & & & 2 \\
\hline Candida sake & 2 & 2.7 & & 2 & & & & \\
\hline $\begin{array}{c}\text { Saccharomyces cf. } \\
\text { cerevisiae/paradoxus }\end{array}$ & 2 & 2.7 & & & 2 & & & \\
\hline Lachancea fermentati & 3 & 5.4 & & 2 & & 1 & & \\
\hline $\begin{array}{l}\text { Curvibasidium } \\
\text { pallidicorallinum }\end{array}$ & 1 & 1.4 & & 1 & & & & \\
\hline Schizosaccharomyces pombe & 1 & 1.4 & & & & 1 & & \\
\hline Brettanomyces bruxellensis & 1 & 1.4 & & & & & 1 & \\
\hline Rhodotorula nothofagi & 1 & 1.4 & 1 & & & & & \\
\hline Pichia manshurica & 1 & 1.4 & & & & 1 & & \\
\hline Total & 74 & 100 & 23 & 7 & 12 & 9 & 7 & 16 \\
\hline
\end{tabular}


One of the expected features of a fermented brew is the presence of Saccharomyces yeasts. The phylogenetic tree based on the Hasegawa-Kishino-Yano model in Figure 3 shows the relationship among the $S$. cerevisiae isolates isolated from the khadi samples. The tree (Figure 3) suggests that S. cerevisiae isolates isolated from different locations are diverse as they cluster into 7 different groups. The results suggest that some brewers could be using commercial ale, baker's yeast, lager and/or wine strains instead of spontaneous fermentation. For example, Group 7 (Figure 3) isolates clustered with a control commercial baker's yeast, which is readily available in local retail shops. In addition, it was noted that some isolates clustered with commercial ale and wine yeasts as shown in Group 4, which are not available in the local supermarkets of Botswana, while two isolates from Maun (MA6) and Letlhakane (L3) clustered in a separate group with the commercial lager yeast. These clusters suggest that commercial yeasts strains have been used as a starter culture. Brewers prefer the addition of starter cultures to circumvent the negative outcomes of spontaneous fermentation, which produces an inconsistent quality of fermented products. Contrastingly, we noted that $S$. cerevisiae strain isolated from G. flava fruits (from Letlhakane) clustered with S. cerevisiae isolates from khadi from Serowe and Mmashoro in Group 5, suggesting that use of spontaneous fermentation could be popular among these two locations. Use of dried fruits from the same supplier in these three locations could also be a possible explanation for the isolation of yeasts that were closely related to isolates from the fruits.

The occurrence of non-conventional yeasts with a wide diversity further suggests that local brewers also depend on spontaneous fermentations other than inoculating with a commercial strain of a yeast species (Table 4). Our assumption is based on the fact that there are no commercial non-conventional yeasts sold in Botswana. The brewers' back-slopping technique could have been responsible for increasing the frequency of non-conventional yeasts to detectable levels. The use of fruits from the same supplier, therefore, could have been the reason for the sharing of starter cultures among brewers, hence the similarity in some cultures.

\subsection{Saccharomyces and Non-Saccharomyces Yeasts Responsible for Fermentation of Khadi}

Yeasts play a pivotal role (ethanol production) in fermentation of all alcoholic beverages [60]. Although S. cerevisiae species were found in low frequencies on G. flava fruits before fermentation, the species dominated the isolates from the fermented product, khadi. All samples were collected from spontaneously fermented brews or from back-slopped brews and, therefore, the fermenting Saccharomyces spp. could be those that were introduced from the ripened sun-dried fruits or previously fermented fruits (inoculum), as well as those resident on the brewing equipment and the brown Table Sugar as reported elsewhere [61].

The diversity of $S$. cerevisiae species isolated from khadi in comparison to the fruits prompted us to further investigate adulteration of the brewing process using readily available commercial S. cerevisiae species sold by retail stores in Botswana. The brewers may add commercial baker's yeasts during khadi production to give it 'strength' and 'enhance its capacity' to intoxicate, instead of relying on spontaneous fermentations [62]. An investigation into the genetic diversity of the Saccharomyces spp. using in-silico PCR-RFLP suggests that most of the isolates were not genetically distinct from the commercial baker's yeast (Figure 4a). To be specific, restriction fragment patterns of $67.5 \%$ of the species of this species (27 out of 40 isolates) digested with HaeIII matched a characteristic restriction fragment pattern of the commercial baker's yeast strain (Figure 4a and see also Figure S1 and Table S4). On the other hand, 13 unique restriction fragment patterns from Mmashoro (AC1MIII, AC2MIII, AC3MIII, AC5MIII, MIAC2 and MIAC3), from Palapye (P10, P14, P16 and P17) and from Letlhakane (LMA4, LMA5 and Z2), which neither matched the S. cerevisiae isolate from fruits nor the commercial baker's, ale, lager and wine species, were observed (Figure 4a). This suggests that there are other sources of fermenting yeasts unaccounted for in this study. One source of yeasts could be equipment used for brewing and pre-processing. Another possibility is that the yeasts were present on the fruit surfaces at lower frequencies to be isolated using the plate count method. The latter is not surprising because different studies have shown that S. cerevisiae is usually found in low frequencies during the beginning 
of spontaneous fermentations as compared to other yeasts, but accounts for the highest densities at the end of fermentation $[30,33]$. On the other hand, there is a possibility that some colonies that had similar macro and microscopic morphology to the S. cerevisiae isolate from fruits were overlooked in an effort to minimize potentially repetitive sequencing.

Digestion with another enzyme, GluI, suggests that there are subgroups within the species (such as C. ethanolica, C. sake, P. kudriavzevii and Saccharomycodes ludwigii) (Figure 4b). There was no restriction fragment pattern of isolates from khadi that matched the pattern of the S. cerevisiae isolate from G. flava fruits. There are several possible scenarios that can explain the absence of this strain as concluded from the restriction fragment patterns after fermentation. That is, the strain could have existed in frequencies too low to be picked amongst other isolates, especially if back slopping was practiced, because the back-slopped inocula (including the wild isolate $S$. cerevisiae isolate from the fruits) could have outcompeted it during the fermentation. In spite of the clustering of some isolates with the commercial baker's yeast (Figure 3), the prevalence of strains of S. cerevisiae with a distinct restriction fragment pattern from that of the commercial baker's yeast suggests that Mmashoro and Letlhakane are the only areas that rely on spontaneous fermentation for brewing of khadi (Figure S1). The in-silico PCR-RFLP results further revealed that none of the khadi isolates had a similar restriction fragment pattern to the selected ale and lager brewing yeasts and wine yeasts used in the industry, even though there were similarities in the sequencing data (Figure 3). These yeasts are not available in the local supermarkets of Botswana as compared to the readily available baker's yeast explaining why they were not prevalent. 


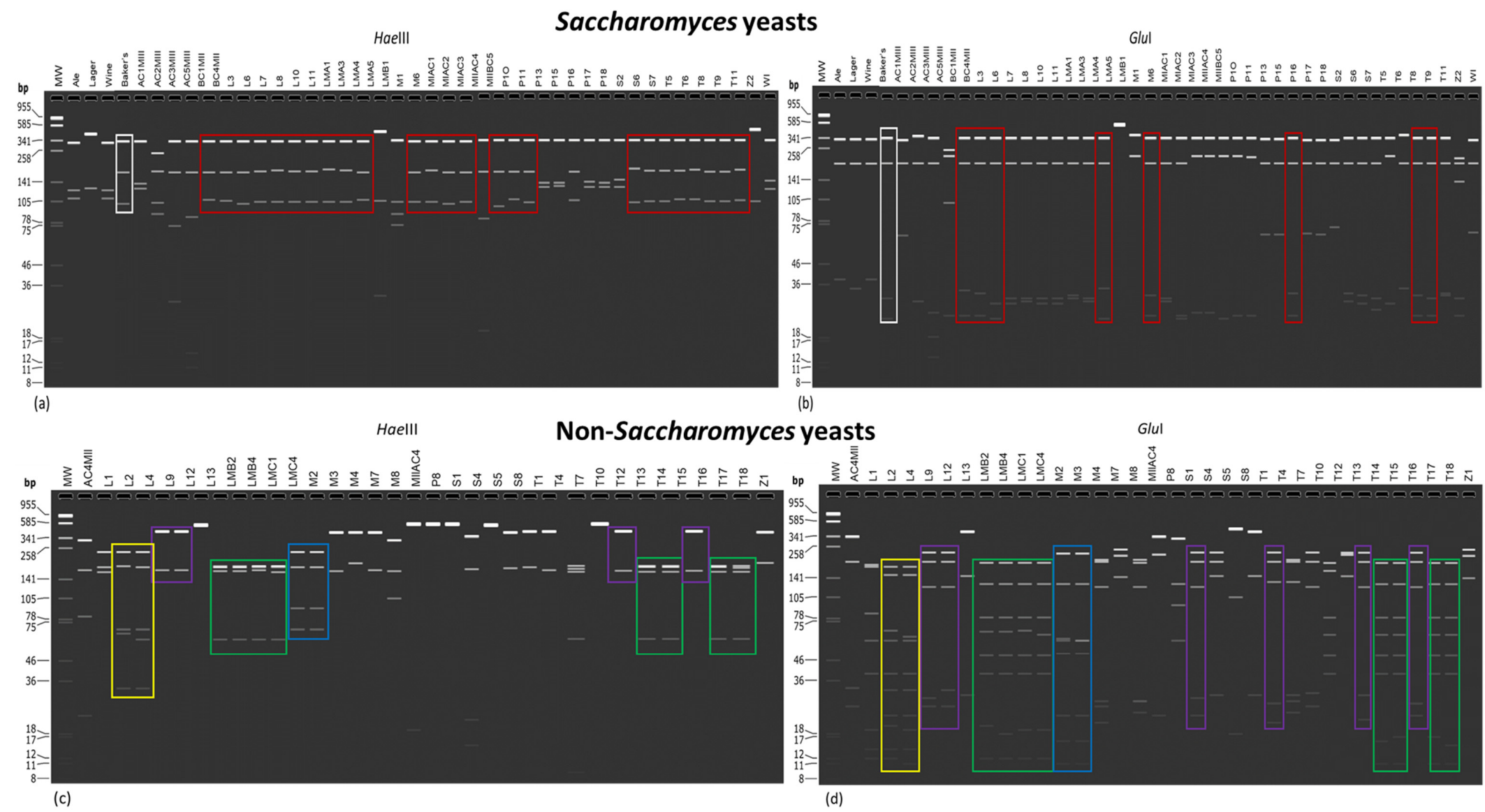

Figure 4. Polymerase chain reaction-restriction fragment length polymorphism (PCR-RFLP) for yeast isolates from khadi. (a) and (b) show restriction fragment patterns of Saccharomyces yeasts obtained using restriction enzymes HaeIII and GluI. The red boxes on (a) and (b) show restriction fragments patterns of isolates that are similar to that of the control commercial baker's yeast (white box). WI is the wild S. cerevisiae isolate from G. flava fruits. (c) and (d) show restriction fragments patterns of non-Saccharomyces yeasts obtained using restriction enzymes HaeIII and GluI. The blue, green, purple and yellow boxes on (c) and (d) show matching restriction fragment patterns for some isolates. 
Non-conventional yeasts could be responsible for fermentation of khadi rather than conventional Saccharomyces yeasts alone. The fermentative lifestyle of species of the genus Saccharomyces is not unique among yeasts of the Saccharomycetaceae family $[39,60,63]$, as it may have coincided with the origin of angiosperms, about 125 million years ago $[63,64]$. Therefore, other non-conventional yeasts in the Saccharomycetaceae family, which evolved in the same time period, are also capable of making and accumulating ethanol. In this study we identified a number of non-conventional yeasts (Tables 4 and 5) which could have also been responsible for fermentation of khadi. Therefore, we further investigated the genetic diversity using in silico PCR-RFLP of non-Saccharomyces yeasts to reveal unique species responsible for fermentation of different brews. We observed that among the genetically diverse yeasts, there were several unique yeasts that could be responsible for khadi fermentation (Figure $4 \mathrm{c}, \mathrm{d}$ ). We noted that C. ethanolica strains isolated from Tonota (T14, T15, T17 and T18) had matching restriction fragment pattern with C. ethanolica strains from Letlhakane (LMB2, LMB4, LMC1 and LMC4) after digestion with HaeIII. These two locations are $200 \mathrm{~km}$ apart and therefore sharing of the back slopped broth or dried fruits is highly unlikely although the ability of yeasts to be dispersed over long distances by insects is well documented $[65,66]$. Therefore, this explains that these species could be naturally occurring on G. flava fruits in a large territory. In agreement to our assertions, strains from a different species, Saccharomycodes ludwigii from khadi from the same locations Tonota (T13, and T16) and Letlhakane (L9 and L12) also had a similar restriction fragment pattern when digested using HaeIII (Figure 4c). Similar results can be observed when running the same experiment using GluI (Figure 4c,d) as seen in Table S3. This suggests the primary source of the fermenting yeasts could have been the fruits and not the fermentation vessels or the equipment used. It is noteworthy that non-Saccharomyces yeasts are not commercially available in Botswana, hence their role in spontaneous fermentation of khadi is supported by the above statement. There has been a rapid expansion of craft breweries that utilize non-Saccharomyces yeasts in the modern brewing industry [67-69]. This strategy has gained special attention due to the demand for innovative and aromatically diverse beers associated with changing global lifestyles [70,71]. Non-Saccharomyces yeasts have been demonstrated to produce a wide range of aromatic compounds and other metabolites that are known to improve the sensorial profiles of alcoholic beverages $[41,43,68]$. This work further increases the attention to exploit these yeasts to define khadi traits towards the development of this traditional beverage. The characterization of these non-Saccharomyces yeasts (not presented in this paper) should be explored to understand how these diverse yeasts reported here could enrich and diversify aromas and flavors. Such studies would pave the way to improvement of the sensory complexity of khadi towards its entry into regional and international markets.

\subsection{Variation in Alcohol Content among Khadi Samples}

The ethanol concentration among the khadi samples investigated ranged from $0.8 \pm 0.11$ to $8.7 \pm$ $0.11 \%(v / v)$ (Figure 5a). The highest ethanol content was recorded from Maun 1 whereas Maun 3 had the lowest ethanol content. Maun 1 has the highest ethanol concentration and its fermentation was carried out by the combination of S. cerevisiae and C. sake. The lowest ethanol concentration was from Maun 3 and its fermentation was carried by Lachancea fermentati and Curvibasidium pallidicorallinum which is an ethanol-tolerant species. On average, ethanol content of khadi was $5.3 \pm 2.55 \%(v / v)$. This value is comparable to the average, $3.7 \%(v / v)$, previously reported by Mapitse et al. [7]. Commercial beers range from 3 to $6 \%(v / v)$ [72] meaning khadi ranges closely to commercial beers. The diversity of fermenting yeasts among khadi samples could be one of the main reasons of the discrepancies of amounts of ethanol accumulated. The biochemical composition of the dried G. flava fruits and the physiological qualities of the yeasts may also limit the ethanol content which depends on the carbohydrate/sugar composition of different batches of fruits. Species from the genus Saccharomyces produce higher amounts of ethanol as compared to other genera and their non-conventional counterparts [63]. In addition, the use of uncontrolled and partially aerobic fermenting vessels could also account for the discrepancies in alcohol content among khadi brews as oxygen levels determine alcoholic fermentation patterns [73]. Lower 
oxygen partial pressures increase the glycolytic flux towards a fermentative metabolism, whereas the opposite is true for environments with high oxygen concentrations [60,74]. It is worth noting that fermentation time is not standardized in the brewing of khadi. Another variable that could account for discrepancies in ethanol concentration is time to completion of fermentation. Time to harvest is not standardized in the brewing of khadi. The amount of ethanol at the end of fermentation of khadi is, therefore, stage- and condition-specific.

\subsection{The $\mathrm{pH}$ of Khadi, an Important Factor in Preservation of the Brew}

The $\mathrm{pH}$ of the khadi samples ranged from 2.6 to 3.6 (Figure 5b, also see Table S5b). Sample Letlhakane 2 and Serowe 2 had the least acidity as compared to all samples, whereas sample Palapye 3 was the most acidic with a $\mathrm{pH}$ of 2.6. The average $\mathrm{pH}$ of all the samples was $3.1 \pm 0.31$ which is in agreement with studies reported by Mapitse et al. [7] who reported an average $\mathrm{pH}$ of $3.1 \pm 0.15$. $\mathrm{pH}$ influences the overall physiological characteristics of alcoholic beverages, such as taste, color and microbiological stability. Most importantly, $\mathrm{pH}$ also strongly influences sanitation of the product, an attribute important for increasing shelf life of the brew [75]. Other than the presence of ethanol, the acidic $\mathrm{pH}$ is likely the other reason why there were no bacteria isolated from khadi. $\mathrm{pH}$ is the primary determinant of the community structure of bacteria, with a large number of bacteria known to be inhibited by low $\mathrm{pHs}$ [76-78]. Although there are other factors, such as mineral content and titratable acidity, among others that should be considered to make valid conclusions on the effects of an acidic brew, the information on the relative acidity of the brew would be important for commercialization of khadi. 


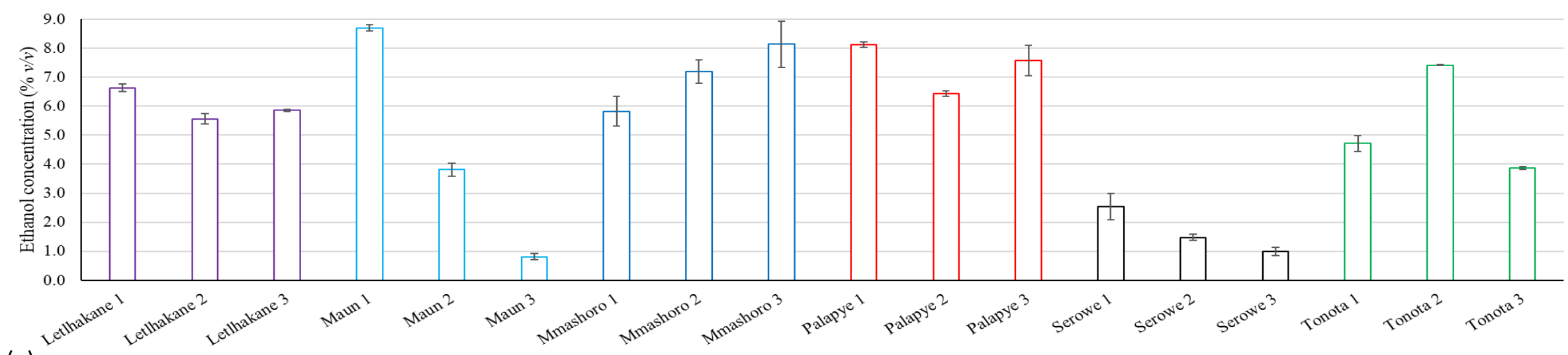

(a)

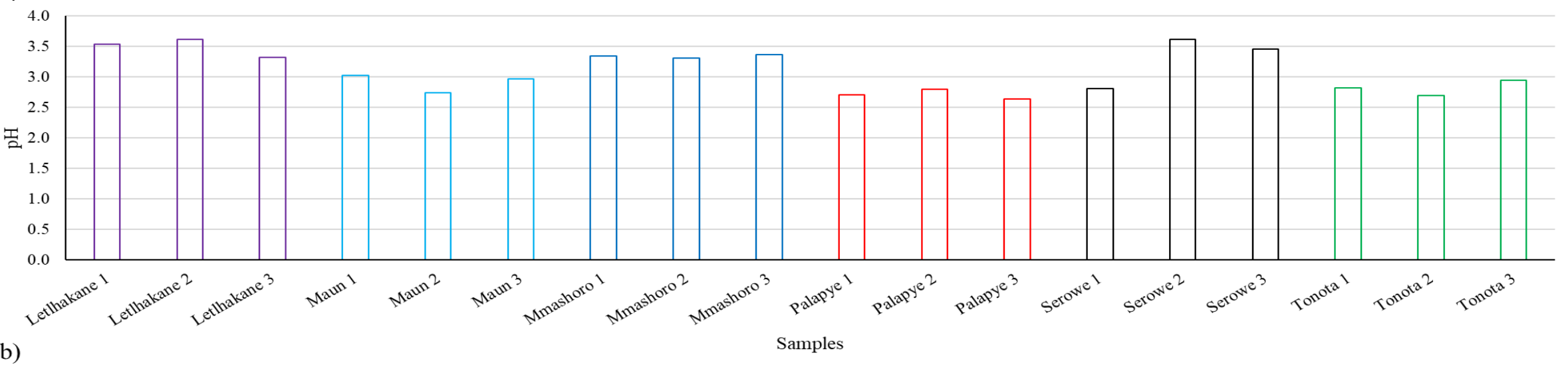

(b)

Figure 5. The physio-chemical properties of the khadi samples. (a) Variable average ethanol content and (b) average $\mathrm{pH}$ of the khadi samples used in the study. Color code: purple $=$ Letlhakane, sky blue $=$ Maun, navy blue $=$ Mmashoro, red $=$ Palapye, Black $=$ Serowe and green $=$ Tonota 


\section{Conclusions}

This study presents the first microbiological characterization of khadi, a popular traditional alcoholic beverage in Botswana. Our work suggests that some khadi brewers practice spontaneous fermentation, whereas others use a commercial baker's yeast. Further studies to test for the functionality of the mixed consortia and resultant aromatic profiles are needed for development of starter cultures for consistent product quality towards commercialization of khadi.

Supplementary Materials: Supplementary materials can be found at http://www.mdpi.com/2311-5637/6/2/51/s1. Figure S1: PCR-RFLP for yeast isolates from khadi. Table S1: The coordinates of the khadi sampling areas. Table S2: The yeast enumeration results in $\log 10 \mathrm{CFU} / \mathrm{mL}$ from khadi. Table S3: PCR-RFLP sizes of all S. cerevisiae strains isolated in this work. Table S4: PCR-RFLP sizes of all non-Saccharomyces strains isolated in this work. Table S5: The ethanol assay test results for the khadi samples.

Author Contributions: K.L., K.M. and N.Z. conceived and designed the experiments. K.M. performed the experiments. K.M., K.L., T.B. and N.Z. wrote the paper. All authors have read and agreed to the published version of the manuscript.

Funding: This research was funded by Botswana International University of Science and Technology Research Office Initiation grants (R00026).

Conflicts of Interest: The authors declare no conflict of interest.

\section{References}

1. Nyanga, L.K.; Nout, M.J.R.; Smid, E.J.; Boekhout, T.; Zwietering, M.H. Fermentation characteristics of yeasts isolated from traditionally fermented masau (Ziziphus mauritiana) fruits. Int. J. Food Microbiol. 2013, 166, 426-432. [CrossRef] [PubMed]

2. Nyanga, L.K.; Nout, M.J.R.; Gadaga, T.H.; Theelen, B.; Boekhout, T.; Zwietering, M.H. Yeasts and lactic acid bacteria microbiota from masau (Ziziphus mauritiana) fruits and their fermented fruit pulp in Zimbabwe. Int. J. Food Microbiol. 2007, 120, 159-166. [CrossRef] [PubMed]

3. Tishkoff, S.A.; Reed, F.A.; Friedlaender, F.R.; Ranciaro, A.; Froment, A.; Hirbo, J.B.; Awomoyi, A.A.; Bodo, J.; Doumbo, O.; Ibrahim, M.; et al. The Genetic Structure and History of Africans and African Americans. J. Sci. 2009, 324, 1035-1044. [CrossRef] [PubMed]

4. Finlay, J.; Jones, R.K. Alcohol Consumption and the Nature of Alcohol Related Problems in Botswana: A Premiliminary Report; Michigen State University: East Lansing, MI, USA, 1982.

5. Leger, S. Overview of bushmen's uses of several plants present at the Kalahari Meerkat Project. In The Hidden Gifts of Nature-A Description of Today's Use of Plants in West Bushmanland (Namibia); German Development Service: Wächtersbach, Germany, 1997; pp. 2-5.

6. Van Wyk, B.E.; Gericke, N. People's plants: A Guide to Useful Plants of Southern Africa; Briza Publications: Johannesburg, South Africa, 2000.

7. Mapitse, R.; Okatch, H.; Moshoeshoe, E. Analysis of Volatile Compounds in Khadi (an Unrecorded Alcohol Beverage) from Botswana by Gas Chromatography-Flame Ionization Detection (GC-FID). South Afr. J. Chem. 2014, 67, 184-188.

8. WHO. Global Status Report on Alcohol; World Heal Organization: Geneva, Switzerland, 2004; pp. 4-6.

9. Swiegers, J.H.; Bartowsky, E.J.; Henschke, P.A.; Pretorius, I.S. Yeast and bacterial modulation of wine aroma and flavour. Aust. J. Grape Wine Res. 2005, 11, 139-173. [CrossRef]

10. Freire, A.L.; Ramos, C.L.; Schwan, R.F. Microbiological and chemical parameters during cassava based-substrate fermentation using potential starter cultures of lactic acid bacteria and yeast. Food Res. Int. 2015, 76, 787-795. [CrossRef]

11. Gadaga, T.H.; Mutukumira, A.N.; Narvhus, J.A.; Feresu, S.B. A review of traditional fermented foods and beverages of Zimbabwe. Int. J. Food Microbiol. 1999, 53, 1-11. [CrossRef]

12. Adekoya, I.; Obadina, A.; Adaku, C.C.; De Boevre, M.; Okoth, S.; De Saeger, S.; Njobeh, P. Mycobiota and co-occurrence of mycotoxins in South African maize-based opaque beer. Int. J. Food Microbiol. 2018, 270, 22-30. [CrossRef]

13. Lyumugabe, F.; Gros, J.; Nzungize, J.; Bajyana, E.; Thonart, P. Characteristics of African traditional beers brewed with sorghum malt: A review. Biotechnol. Agron. Soc. Environ. 2012, 16, 509-530. 
14. Lee, Y.; Choi, Y.; Lee, S.; Park, J.; Shim, J.; Park, K.; Kim, W. Screening Wild Yeast Strains for Alcohol Fermentation from Various Fruits. Mycobiology 2011, 39, 33-39. [CrossRef]

15. Kurtzman, C.P.; Robnett, C.J. Identification and phylogeny of ascomycetous yeasts from analysis of nuclear large subunit ( 26S ) ribosomal DNA partial sequences. Antonie Leeuwenhoek 1998, 98, 331-371. [CrossRef] [PubMed]

16. Lõoke, M.; Kristjuhan, K.; Kristjuhan, A. Extraction of genomic DNA from yeasts for PCR based applications. Biotechniques 2011, 50, 325-328. [CrossRef] [PubMed]

17. Ouoba, L.I.I.; Diawara, B.; Amoa-Awua, W.K.; Traoré, A.S.; Møller, P.L. Genotyping of starter cultures of Bacillus subtilis and Bacillus pumilus for fermentation of African locust bean (Parkia biglobosa) to produce Soumbala. Int. J. Food Microbiol. 2004, 90, 197-205. [CrossRef]

18. Kumar, S.; Stecher, G.; Tamura, K. MEGA7: Molecular Evolutionary Genetics Analysis Version 7.0 for Bigger Datasets. Mol. Biol. Evol. 2018, 33, 1870-1874. [CrossRef] [PubMed]

19. Tamura, K.; Nei, M. Estimation of the number of nucleotide substitutions in the control region of mitochondrial DNA in humans and chimpanzees. Mol. Biol. Evol. 1993, 10, 512-526. [CrossRef]

20. Kurtzman, C.P.; Fell, J.W.; Boekhout, T.; Robert, V. Methods for isolation, phenotypic characterization and maintenance of yeasts. In The Yeasts; Elsevier B.V.: Amsterdam, The Netherlands, 2011; Volume 1, pp. 87-110. ISBN 9780444521491.

21. Fleet, G.H. Yeasts in fruit and fruit products. In Yeasts in Food; B. Behr's Verlag GmbH \& Co.: Heidelberg, Germany, 2003; pp. 267-287. ISBN 9781845698485.

22. Valente, A.; Sanches-Silva, A.; Albuquerque, T.G.; Costa, H.S.; Transfer, T.; Conference, I.I.; Kozhahmetova, Z.; Kasenova, G.; Sedláček, I.; Nováková, D.; et al. Microbiological and chemical parameters during cassava based-substrate fermentation using potential starter cultures of lactic acid bacteria and yeast. Int. J. Food Microbiol. 2017, 5, 1-11. [CrossRef]

23. Styger, G.; Prior, B.; Bauer, F.F. Wine flavor and aroma. J. Ind. Microbiol. Biotechnol. 2011, 38, 1145-1159. [CrossRef]

24. Fotedar, R.; Kolecka, A.; Boekhout, T.; Fell, J.W.; Al-Maliki, A.; Zeyara, A.; Al Marri, M. Fungal diversity of the hypersaline Inland Sea in Qatar. Bot. Mar. 2018, 61, 595-609. [CrossRef]

25. Varela, C. The impact of non-Saccharomyces yeasts in the production of alcoholic beverages. Appl. Microbiol. Biotechnol. 2016, 100, 9861-9874. [CrossRef]

26. Barata, A.; Malfeito-Ferreira, M.; Loureiro, V. The microbial ecology of wine grape berries. Int. J. Food Microbiol. 2012, 153, 243-259. [CrossRef]

27. Moubasher, A.-A.H.; Abdel-Sater, M.A.; Soliman, Z.S.M. Diversity of floricolous yeasts and filamentous fungi of some ornamental and edible fruit plants in assiut area, egypt. Curr. Res. Environ. Appl. Mycol. 2018, 8, 135-161. [CrossRef]

28. Cousin, F.; Le Guellec, R.; Schlusselhuber, M.; Dalmasso, M.; Laplace, J.-M.; Cretenet, M. Microorganisms in fermented apple beverages: Current Knowledge and Future Directions. Microorganisms 2017, 5. [CrossRef]

29. Pretorius, I.S. Tailoring wine yeast for the new millennium: Novel approaches to the ancient art of winemaking. Yeast 2000, 16, 675-729. [CrossRef]

30. Goddard, M.R. Quantifying the complexities of Saccharomyces cerevisiae's ecosystem engineering via fermentation. Ecol. Soc. Am. 2008, 89, 2077-2082.

31. Mortimer, R.; Polsinelli, M. On the origins of wine yeast. Res. Microbiol. 1999, 150, 199-204. [CrossRef]

32. Ponzzes-Gomes, C.M.P.B.S.; De Mélo, D.L.F.M.; Santana, C.A.; Pereira, G.E.; Mendonça, M.O.C.; Gomes, F.C.O.; Oliveira, E.S.; Barbosa, A.M., Jr.; Trindade, R.C.; Rosa, C.A. Saccharomyces cerevisiae and nonSaccharomyces yeasts in grape varieties of the São Francisco Valley. Braz. J. Microbiol. 2014, 45, 411-416. [CrossRef]

33. Dashko, S.; Zhou, N.; Compagno, C. Why, when and how did yeast evolve alcoholic fermentation? FEMS Yeast Res. 2014, 14. [CrossRef]

34. Zhou, N.; Bottagisi, S.; Katz, M.; Schacherer, J.; Friedrich, A.; Gojkovic, Z.; Swamy, K.B.S.; Knecht, W.; Compagno, C.; Piškur, J. Yeast-bacteria competition induced new metabolic traits through large-scale genomic rearrangements in Lachancea kluyveri. FEMS Yeast Res. 2017, 17. [CrossRef]

35. Cortesão, M.; Fuchs, F.M.; Commichau, F.M.; Eichenberger, P.; Schuerger, A.C.; Nicholson, W.L.; Setlow, P.; Moeller, R. Bacillus subtilis spore resistance to simulated mars surface conditions. Front. Microbiol. 2019, 10, 1-16. [CrossRef] 
36. Regalado, N.G.; Martin, G.; Antony, S.J. Acinetobacter lwoffii: Bacteremia associated with acute gastroenteritis. Travel Med. Infect. Dis. 2009, 7, 316-317. [CrossRef]

37. Pal Singh, N.; Sagar, T.; Nirmal, K.; Rajender Kaur, I. Pyogenic liver abscess caused by Acinetobacter lwoffii: A case report. J. Clin. Diagn. Res. 2016, 10, DD01-DD02. [CrossRef]

38. Ugbogu, O.C.; Ogodo, A.C. Microbial Flora, Proximate Composition and Vitamin Content of Juices of Three Fruits Bought from a Local Market in Nigeria. Int. J. Chem. Eng. Appl. 2015, 6, 440-443. [CrossRef]

39. Rozpedowska, E.; Hellborg, L.; Ishchuk, O.P.; Orhan, F.; Galafassi, S.; Merico, A.; Woolfit, M.; Compagno, C.; Piškur, J. Parallel evolution of the make-accumulate-consume strategy in Saccharomyces and Dekkera yeasts. Nat. Commun. 2011, 2, 302. [CrossRef]

40. Lencioni, L.; Romani, C.; Gobbi, M.; Comitini, F.; Ciani, M.; Domizio, P. Controlled mixed fermentation at winery scale using Zygotorulaspora florentina and Saccharomyces cerevisiae. Int. J. Food Microbiol. 2016, 234, 36-44. [CrossRef] [PubMed]

41. Andorrà, I.; Berradre, M.; Mas, A.; Esteve-Zarzoso, B.; Guillamón, J.M. Effect of mixed culture fermentations on yeast populations and aroma profile. Lwt Food Sci. Technol. 2012, 49, 8-13. [CrossRef]

42. Ciani, M.; Comitini, F.; Mannazzu, I.; Domizio, P. Controlled mixed culture fermentation: A new perspective on the use of non-Saccharomyces yeasts in winemaking. FEMS Yeast Res. 2009, 10, 123-133. [CrossRef] [PubMed]

43. Dashko, S.; Zhou, N.; Tinta, T.; Sivilotti, P.; Lemut, M.S.; Trost, K.; Gamero, A.; Boekhout, T.; Butinar, L.; Vrhovsek, U.; et al. Use of non-conventional yeast improves the wine aroma profile of Ribolla Gialla. J. Ind. Microbiol. Biotechn. 2015, 42, 997-1010. [CrossRef]

44. Gamero, A.; Quintilla, R.; Groenewald, M.; Alkema, W.; Boekhout, T.; Hazelwood, L. High-throughput screening of a large collection of non-conventional yeasts reveals their potential for aroma formation in food fermentation. Food Microbiol. 2016, 60, 147-159. [CrossRef]

45. Porter, T.J. Biochemical Characterization and Evaluation of the Oenological Attributes of Lachancea Species. MSc Thesis (MScAgric), Stellenbosch University, Stellenbosch, South Africa, 2017.

46. Cordero-Bueso, G.; Esteve-Zarzoso, B.; Cabellos, J.M.; Gil-Diaz, M.; Arroyo, T. Biotechnological potential of non-Saccharomyces yeasts isolated during Biotechnological potential of non- Saccharomyces yeasts isolated during spontaneous fermentations of Malvar (Vitis vinifera cv. L.). Eur. Food Res. Technol. 2012, 236, 2564-2568. [CrossRef]

47. Romano, P.; Suzzi, G.; Domizio, P.; Fatichenti, F. Secondary products formation as a tool for discriminating non- Saccharomyces wine strains Strain diversity in non- Saccharomyces wine yeasts. Antonie Van Leeuwenhoek 1997, 77, 239-242. [CrossRef]

48. Maturano, Y.P.; Assof, M.; Fabani, M.P.; Nally, M.C.; Jofré, V.; Rodríguez Assaf, L.A.; Toro, M.E.; Castellanos De Figueroa, L.I.; Vazquez, F. Enzymatic activities produced by mixed Saccharomyces and non-Saccharomyces cultures: Relationship with wine volatile composition. Antonie Van Leeuwenhoek 2015, 108, 1239-1256. [CrossRef] [PubMed]

49. James, S.A.; Stratford, M. Spoilage yeasts with emphasis on the genus Zygosaccharomyces. In Yeasts in Food; B. Behr's Verlag GmbH \& Co.: Heidelberg, Germany, 2003; pp. 171-191. ISBN 9781845698485.

50. Schifferdecker, A.J.; Siurkus, J.; Andersen, M.R.; Joerck-Ramberg, D.; Ling, Z.; Zhou, N.; Blevins, J.E.; Sibirny, A.A.; Piškur, J.; Ishchuk, O.P. Alcohol dehydrogenase gene ADH3 activates glucose alcoholic fermentation in genetically engineered Dekkera bruxellensis yeast. Appl. Microbiol. Biotech. 2016, 100, 3219-3231. [CrossRef] [PubMed]

51. Alonso, A.; Belda, I.; Santos, A.; Navascués, E.; Marquina, D. Advances in the control of the spoilage caused by Zygosaccharomyces species on sweet wines and concentrated grape musts. Food Control 2015, 51, 129-134. [CrossRef]

52. Chatonnet, P.; Dubourdieu, D.; Boidron, J.N. The Influence of <em $>$ Brettanomyces/Dekkera sp. Yeasts and Lactic Acid Bacteria on the Ethylphenol Content of Red Wines. Am. J. Enol. Vitic. 1995, 46, 463-468.

53. Licker, J.L.; Acree, T.E.; Henick-Kling, T. What Is "Brett" (Brettanomyces) Flavor?: A Preliminary Investigation. ACS Symp.Ser. 1998, 96-115. [CrossRef]

54. Hittinger, C.T.; Rokas, A.; Bai, F.Y.; Boekhout, T.; Gonçalves, P.; Jeffries, T.W.; Kominek, J.; Lachance, M.A.; Libkind, D.; Rosa, C.A.; et al. Genomics and the making of yeast biodiversity. Curr. Opin. Genet. Dev. 2015, 35, 100-109. [CrossRef] 
55. Schifferdecker, A.J.; Dashko, S.; Ishchuk, O.P.; Piškur, J. The wine and beer yeast Dekkera bruxellensis. Yeast 2014, 31, 323-332. [CrossRef]

56. Capece, A.; Romaniello, R.; Siesto, G.; Romano, P. Conventional and Non-Conventional Yeasts in Beer Production. Fermentation 2018. [CrossRef]

57. Xu, Y.; Zhi, Y.; Wu, Q.; Du, R.; Xu, Y. Zygosaccharomyces bailii is a potential producer of various flavor compounds in Chinese Maotai-flavor liquor fermentation. Front. Microbiol. 2017, 8, 1-9. [CrossRef]

58. Douglass, A.P.; Offei, B.; Braun-galleani, S.; Coughlan, A.Y.; Ortiz-merino, A.; Byrne, K.P.; Wolfe, K.H.; Martos, A.A.R. Population genomics shows no distinction between pathogenic Candida krusei and environmental Pichia kudriavzevii: One species, four names. PLoS Path. 2018, 14, e1007138. [CrossRef]

59. Ramos, C.L.; De Sousa, E.S.O.; Ribeiro, J.; Almeida, T.M.M.; Santos, C.C.A.D.A.; Abegg, M.A.; Schwan, R.F. Microbiological and chemical characteristics of tarubá, an indigenous beverage produced from solid cassava fermentation. Food Microbiol. 2015, 49, 182-188. [CrossRef] [PubMed]

60. Piškur, J.; Rozpedowska, E.; Polakova, S.; Merico, A.; Compagno, C. How did Saccharomyces evolve to become a good brewer? Trends Genet. 2006, 22, 183-186. [CrossRef] [PubMed]

61. Boekhout, T.; Phaff, H.J. Yeast biodiversity. In Yeasts in Food; B. Behr's Verlag GmbH \& Co.: Heidelberg, Germany, 2003; pp. 1-38. ISBN 9781845698485.

62. Von Rudloff, A.; Mogkatlhe, L.; Mookodi, G. Botswana: Summary of nationwide research, in International Center for Alcohol Policies (ed.), Producers, Sellers, and Drinkers: Studies of Non-commercial Alcohol in Nine Countries. Glob. Actions Harmful Drink. 2012, 13-18. Available online: http://iardwebprod.azurewebsites.net/getattachment/9725694a-dbdb-4f27-b581-5211004e0b3c/icapproducers-sellers-and-drinkers-noncommercial-alcohol-monograph.pdf (accessed on 8 May 2020).

63. Hagman, A.; Sall, T.; Compagno, C.; Piskur, J. Yeast “Make-Accumulate-Consume” Life Strategy Evolved as a Multi-Step Process That Predates the Whole Genome Duplication. PLoS ONE 2013, 8. [CrossRef] [PubMed]

64. Sun, G.; Dilcher, D.L.; Wang, H.; Chen, Z. A eudicot from the Early Cretaceous of China. Nature 2011, 471, 625-628. [CrossRef] [PubMed]

65. Baselga, I.; Zafra, O.; Pérez, L.E.; Francisco-Alvarez, R.; Rodriguez-Tarduchy, G.; Santos, C. An AFLP based method for the detection and identification of indigenous yeast in complex must samples without a microbiological culture. Int. J. Food Microbiol. 2017, 241, 89-97. [CrossRef]

66. Steensels, J.; Daenen, L.; Malcorps, P.; Derdelinckx, G.; Verachtert, H.; Verstrepen, K.J. Brettanomyces yeasts-From spoilage organisms to valuable contributors to industrial fermentations. Int. J. Food Microbiol. 2015, 206, 24-38. [CrossRef]

67. Alfeo, V.; Todaro, A.; Migliore, G.; Borsellino, V.; Schimmenti, E. Microbreweries, brewpubs and beerfirms in the Sicilian craft beer industry. Int. J. Wine Bus. Res. 2019, 32, 122-138. [CrossRef]

68. Callejo, M.J.; González, C.; Morata, A. Use of Non-Saccharomyces Yeasts in Bottle Fermentation of Aged Beers. In Brewing Technology; Intech open: London, UK, 2017. [CrossRef]

69. Iattici, F.; Catallo, M.; Solieri, L. Designing New Yeasts for Craft Brewing: When Natural Biodiversity Meets Biotechnology. Beverages 2020, 6, 3. [CrossRef]

70. Michel, M.; Meier-Dörnberg, T.; Jacob, F.; Methner, F.J.; Wagner, R.S.; Hutzler, M. Review: Pure non-Saccharomyces starter cultures for beer fermentation with a focus on secondary metabolites and practical applications. J. Inst. Brew. 2016, 122, 569-587. [CrossRef]

71. Ravasio, D.; Carlin, S.; Boekhout, T.; Groenewald, M.; Vrhovsek, U.; Walther, A.; Wendland, J. Adding Flavor to Beverages with Non-Conventional Yeasts. Fermentation 2018, 4, 15. [CrossRef]

72. Bamforth, C.W. Nutritional aspects of beer-A review. Nutr. Res. 2002, 22, 227-237. [CrossRef]

73. Merico, A.; Galafassi, S.; Piškur, J.; Compagno, C. The oxygen level determines the fermentation pattern in Kluyveromyces lactis. FEMS Yeast Res. 2009, 9, 749-756. [CrossRef]

74. Pronk, J.T.; Steensma, H.Y.; Van Dijken, J.P. Pyruvate metabolism in Saccharomyces cerevisiae. Yeast 1996, 12, 1607-1633. [CrossRef]

75. Jukić, M.; Mastanjević, K.; Lukinac, J.; Vulin, Z.; Mastanjević, K.; Krstanović, V. Beer-The Importance of Colloidal Stability (Non-Biological Haze). Fermentation 2018, 4, 91. [CrossRef]

76. Hirshfield, I.N.; Terzulli, S.; O’Byrne, C. Weak organic acids: A panoply of effects on bacteria. Sci. Prog. 2003, 86, 245-269. [CrossRef] [PubMed] 
77. Yu, H.; Huang, G.H.; Zhang, X.D.; Huang, G.H.; Li, Y. Inhibitory effects of organic acids on bacteria growth during food waste composting. Compos. Sci. Util. 2010, 18, 55-63. [CrossRef]

78. Chelule, P.; Mokoena, M.; Gqaleni, N. Advantages of traditional lactic acid bacteria fermentation of food in Africa. Curr. Res. Technol. Educ. Top. Appl. Microbiol. Microb. Biotechnol. 2010, 2, 1160-1167.

(C) 2020 by the authors. Licensee MDPI, Basel, Switzerland. This article is an open access article distributed under the terms and conditions of the Creative Commons Attribution (CC BY) license (http://creativecommons.org/licenses/by/4.0/). 